\title{
SIKAP KEAGAMAAN DAN POTENSI RADIKALISME AGAMA MAHASISWA PERGURUAN TINGGI AGAMA
}

\author{
Wahid Khozin \\ Peneliti Puslitbang Pendidikan Agama Dan Keagamaan \\ Badan Litbang dan Diklat Kementerian Agama RI \\ Jl. MH Thamrin No. 06 Jakarta Pusat \\ Email:wah_zinmi@yahoo.com
}

\begin{abstract}
This writing is based on the research result data of the Radicalism Potencies in the Islamic Higher Education (Perguruan Tinggi Agama/PTA) students. This study uses the survey approaches which are done in 10 provinces with the target population consists of PTA students of Islam, Catholic, Christian, Hindu and Buddha, with the aims to know the understanding and social-politics of the religious attitudes, as well as the radicalism potencies in PTA. The result shows: 1) the tendency of the radical religious attitudes of the PTA Students, but it is still on the lower level; 2) the tendency of sectarian way of thinking especially in the relation of religious norm positivization on social-state life; 3) the tendency of religious-political orientation; 4) the tendency of the support toward the use of violent media to actualize the religious messages.
\end{abstract}

Keywords: radicalism potencies, sectarian way of thinking, religious-political orientation.

\begin{abstract}
Abstrak
Tulisan ini berbasis data hasil penelitian tentang Potensi Radikalisme di Kalangan mahasiswa pendidikan tinggiagama (PTA). Studi ini menggunakan pendekatan survei yang dilakukan di 10 provinsi dengan populasi target adalah mahasiswa PTA Islam, Katolik, Kristen, Hindu dan Buddha, dengan tujuan mengetahui pemahaman dan sikap social-politik keagamaan, serta potensi radikalisme di kalangan mahasiswa di PTA. Hasilnya menunjukkan: 1) adanya kecenderungan sikap keagamaan yang radikal mahasiswa PTA, tetapi masih taraf rendah;2) adanya kecenderungan cara berpikir sektarian terutama berkaitan dengan positivisasi norma agama dalam kehidupan kenegaraan; 3) adanya kecenderungan orientasi politik keagamaan; dan 4) adanya kecenderungan dukungan terhadap penggunaan media kekerasan untuk mengaktualisasikan pesan-pesan agama.
\end{abstract}

Kata kunci: potensi radikalisme, cara berpikir sektarian, orientasi politik keagamaan

\section{PENDAHULUAN}

Tahun 2000-an, seiring dengan keruntuhan reĝim Orde Baru, gerakan Islam garis keras semakin semarak. Gerakan ini lahir dan berkembang dengan berlindung di balik wacana demokrasi, kebebasan dan hak asasi manusia.
Politik demokrasi memberi kesempatan yang sama untuk kemunculan beragam aliran keagamaan, termasuk paham keagamaan anti mainstream. Dalam bingkai demokrasi, sikap toleran adalah harga mati untuk menyikapi perbedaan dengan segala dampak turunannya. Ironisnya, ketidakdewasaan sikap sosial-politik 
telah melahirkan banyak kontradiksi, dan tragedi dalam keragaman. Pemaksaan kehendak belakangan sering mengental dalam kesadaran kolektif kelompok yang radikal. Saat aspirasi satu kelompok radikal belum tercapai, gejala kekerasan menjadi fenomena lazim. Bom bunuh menjadi gaya jihad orang militan pinggiran, terbuang yang kehilangan harapan untuk berjuang terbuka untuk menyuarakan aspirasi dengan santun, damai dan toleran.

Kegelisahan mental spiritual ini menguat, dan semakin mengental dengan publikasi massal buku-buku yang mengajarkan paham gerakan jihad, dan kembali ke sistem khilâfah Islam. Paham fundamentalisme berperan penting dalam konstruksi realitas ini. Dengan ciri khas kerinduan kembali ke era ideal paling awal Islam dengan sistem khilâfah, dan kecenderungan memperlakukan teks-teks suci agama secara literal, fundamentalisme Islam mengajak warganya untuk menolak kompromi terhadap tafsir ajaran agama guna mengatasi segala tantangan kekinian dan kedisinian. Hizbut Tahrir Indonesia dikenal sebagai faksi yang gencar menyuarakan aspirasi kembali ke sistem khilâfah. Sentimen dan romantisisme religius model ini ditangkap dengan cerdas dan ditransformasikan oleh elit politik tertentu, yang kemudian memproklamasikan partai berbasis agama, dan berharap dapat mendulang suara dalam pemilihan umum dengan mengeksploitasi sentimen agama dan primordialisme. Dari rahim politik Islam lahir Partai Keadilan Ssejahtera. Para politisi Kristiani tidak mau ketinggalan. Mereka memproklamasikan Partai Damai Sejahtera.

Fenomena radikalisme agama menjadi semakinterkuak diranah kampus saatadaalumni perguruan tinggi agama Islam terlibat dalam jaringan teoris internasional. ${ }^{1}$ Di daerah lain,

1 Mahasiswa PTU lebih rentan terhadap usaha rekruitmen untuk menjadi anggota gerakan radikal daripada mahasiswa PTA Islam. Gejala ini berkaitan dengan kenyataan bahwa cara pandang mahasiswa PTU khususnya bidang sains dan teknologi, cenderung melihat masalah agama secara hitam putih. Sebaliknya, mahasiswa PTA Islam yang mendapat keragaman perspektif kampus menjadi lahan subur untuk menyemai benih, dan merekruit pegiat radikalisme dan gerakan Negara Islam Indonesia. Kampus menjadi target khusus operasi rekruitmen simpatisan gerakan ini. Banyak mahasiswa menghilang dengan membawa pergi aset keluarga dan miliknya, lalu terjebak dalam lingkaran aksi keagamaan radikal dan eksklusif. Ringkasnya, kampus dan civitas akademiknya, baik PTA atau kampus-kampus PTU, sungguh tidak steril, dan kebal dari jangkauan paham keagamaan fundamentalis dan radikal.

Kenapa radikalisme di kampus agama harus disorot? Data statistik tentang profil PTA Islam Negeri 2011 menunjukkan trend peningkatan jumlah mahasiswa yang cukup signifikan, terutama di UIN, dan PTA negeri lainnya. Jumlah input mahasiswayang beragam telah menjadikan PTA rentan terhadap potensi radikalisme. Di sisi lain, kegigihan etos gerakan radikal telah menjadikan fenomena radikalisme nyaris merata di berbagai segmen dan ranah masyarakat dan lembaga pendidikan. Bagaimana model paham keagamaan dan potensi radikalisme di kalangan mahasiswa PTA? Apakah paham keagamaan dan potensi radikalisme di kalangan mahasiswa PTA bervariasi menurut basis agama? Apakah faktorfaktor sosial-keagamaan yang mempengaruhi potensi radikalisme tersebut?

Fokus bahasan dalam tulisan ini adalah model pemahaman dan sikap sosial-politik keagamaan, potensi radikalisme agama di kalangan mahasiswa PTA. Inti masalah utama ini dirinci sebagai berikut:

a. Bagaimana model paham dan sikap sosialpolitik keagamaan, dan potensi radikalisme keagamaan di kalangan mahasiswa PTA?

b. Apakah model pemahaman dan sikap sosial-politik keagamaan serta potensi radikalisme agama di kalangan mahasiswa PTA bervariasi menurut basis agama?

tentang Islam cenderung lebih terbuka dan bernuansa kontekstual dalam memahami ajaran Islam. Azyumardi Azra, Kompas, 27 April 2011. 
c. Bagaimana wujud ekspresi radikalisme di kalangan mahasiswa PTA?

Penelitian ini dilakukan di 10 propinsi dengan mengambil poppulasi mahasiswa perguruan tinggi agama Islam, Katolik, Protenstan, Hindu dan Budha. Metode yang digunakan adalah metode survey dengan penetapan sampel multistage random smpling dengan basis deaftar hadir perkuliahan semester genap 2012.

\section{Review Studi Terdahulu}

Beberapa studi terdahulu yang relevan dengan tema bahasan ini. Rangkaian studi terdahulu tentang radikalisme gaya agama cenderung; (1) bercorak kualitatif-teoritis; (2) jika kuantitatif, analisisnya masih terbatas pada model deskripsi univariate, ${ }^{2}$ dan tidak berusaha menjelaskan fenomena radikalisme dari sejumlah faktor yang secara teoritis diyakini berpengaruh simultan terhadap radikalisme agama; (3) bahkan model studi yang ada terfokus pada analisis berbasis paradigma teori sosial yang mempostulasi radikalisme sebagai residu deprivasi (sosial, politik dan ekonomi); (4) menelusuri sejarah dan jaringan; ${ }^{3}$ dan (5) pemetaan watak khusus ideologi dan ajaran

\footnotetext{
2 Ismail Hasani, et.al. 2011, Radikalisme Agama di Jabodetabek dan Jawa Barat: Implikasinya terhadap Jaminan Kebebasan Keragaman/Berkeyakinan. Jakarta: Setara Institute. Lembaga Kajian Islam dan Perdamaian, (2010); Tim Survei, Laporan Penelitian. 2011. Ancaman bagi Ideologi Negara melalui Radikalisme Agama, Jakarta: Lembaga Penelitian Uhamka, 2011.

${ }^{3}$ S.Yunanto, et.al. 2002. Gerakan Militan Islam di Indonesia dan di Asia Tenggara, Jakarta: The Ridep Institute, Greg Fealy dan Anthony Bubalo. 2007. Jejak Kafilah: Pengaruh Radikalisme Timur Tengah Di Indonesia. Bandung: Mizan; M. Zaki Mubarak. 2008. Genealogi Islam Radikal di Indonesia: Gerakan, Pemikiran dan Prosepek Demokrasi. Jakarta. LP3ES. Aguk I. 2011. Mizan, "Melacak Akar Radikalisme dalam Gerakan Islam Modern", Analisis, Vol. XI, No. 1. Noorhaidi Hasan. 2006, Laskar Jihad: Islam, Militancy and the Quest for Identity in Post-New Order Indonesia. Ithaca. New York. SEAP Cornell University. Reformasi, Religious Diversity, and Islamic Radicalism after Suharto, Journal of Indonesian Social Sciences and Humanities, Vol. 1 (2008); van Bruinessen, 'Genealogies of Islamic Radicalism in Post-Suharto
} Indonesia', South East Asian Research. Vol. 10. No. 2 (2002). kelompok radikal. ${ }^{4}$ Satu hal lain yang harus dicatat bahwa studi terdahulu tidak ada yang secara khusus meneliti radikalisme di kalangan mahasiswa PTA, dari perspektif kuantitatif. ${ }^{5}$

Sebagian hasil studi terdahulu telah diringkas di bagian awal tulisan. Bagian ini hanya mereview sisi yang belum dibahas sebelumnya. Pertama, survei Lemlit Uhamka 2012 menunjukkan bahwa sebagian besar responden muslim diJakarta masih merindukan kehadiran negara Islam. Hasil Studi Lembaga Survei Indonesia 2011 dengan sampel nasional yang representatif (kesalahan pencuplikan $\leq 3$ \%) menemukan fakta bahwa lebih dari separo responden remaja muslim setuju dengan gagasan penerapan hukum Islam yang identik dengan semangat hukum yang diidealisasikan kelompok radikal, (hukuman qishosh bagi pembunuh, hukuman cambuk untuk pemabuk, dan hukuman potong tangan bagi pencuri).

Kedua, penelitian LAKIP, 2011 dengan sampel random, menemukan fenomena lain dari cara beragama. Penelitian ini melibatkan 590 responden dari total 2.639 guru PAI, dan 993 siswa muslim di SMU dari total 611.678 murid SMU se-Jabodetabek. Untuk kasus ekspresi radikal, survei ini menemukan fakta bahwa 63 $\%$ responden merestui penggunaan kekerasan untuk hajat agama. Studi hasil kerjasama Pusat Penelitian dan Pengembangan Pendidikan Agama dan Keagamaan, Departemen Agama dengan LabSosio Universitas Indonesia 2005, menguatkan sinyalemen di atas. Penelitian ini menemukan beberapa realitas unik dari

${ }^{4}$ LabSosio UI dan Puslitbang Penda Balitbang Departemen Agama. 2005. laporan akhir penelitian Pola Aktivitas Kelompok Keaagamaan di Kalangan Mahasiswa Pasca Reformasi (Studi Kasus di 6 PTUN). Jakarta, Balitbang Departemen Agama.; Jamhari dan Jajang Jahroni (Ed.). 2004, Gerakan Salafi Radikal Di Indonesia, Jakarta: Rajawali Pers. Syamsul Bahri. 2004. Islam dan Wacana Radikalisme Agama Kontemporer, Dinika, Vol. 3, No. 1; C. Van Dijk. 1981, Rebellion under the Banner of Islam: Darul Islam in Indonesia. The Hague: Martinus Nijhoff.

${ }^{5}$ Saifuddin. 2011. Radikalisme Islam di Kalangan Mahasiswa: Sebuah Metamorfosa Baru, Analisis, Vol. XI, No.1. Studi ini hanya meringkas hasil studi terdahulu dan sedikit menyinggung tentang girah gerakan keagamaan Islam radikal di lingkungan kampus perguruan tinggi. 
kehidupan keagamaan kampus. Pertama, di kalangan mahasiswa Islam terdapat sejumlah grup aktivis agama yang menjadi icon penggerak dan pentolan panutan dalam kegiatan keagamaan. Kedua, gerakan mereka dikelola dalam wujud kajian dan aktivitas keagamaan yang bersistem halaqah. Sumber rujukannya adalah literatur terjemahan karya ulama Timur Tengah yang sering mengedepankan doktrin salafi-tekstualis. Pendidikan model ini berfokus pada model mentor-murabbi yang terpercaya dengan konsistensi dan kontinuitas sistem kaderisasi, bekerja dalam sistem jaringan, terkelola dengan baik, serta menjaga rapih simbol-simbol tradisionalisme yang mereka diusung, seperti cadar, atribut jilbab panjang, jenggot dan celana menggantung di atas mata kaki.

Terakhir, studi Lazuardi Birru memetakan indeks radikalisme di Indonesia. Menurut studi tersebut, indeks radikalisme tahun 2011 mengalami penurunan dibandingkan indeks yang sama pada tahun sebelumnya, tetapi belum dalam batas aman, nyaman. Indeks kerentanan radikalisme di Indonesia 2011, adalah 43.6 dari 100 point. Indeks ini turun 1.44 point dibanding tahun 2010 (45.4), dengan level aman adalah 33.3. Berdasarkan hasil penelitian kerentanan radikalisme di 33 provinsi di Indonesia, 3 daerah paling rentan, rawan terhadap tindakan radikal berbasis agama, yakni Aceh dengan indeks kerentanan 56.8, Jawa Barat (46.6), dan Banten (46.6).

\section{Kerangka Teori}

Tulisan ini berusaha untuk memetakan model sikap keagamaan kalangan mahasiswa PTA. Sikap dalam studi ini dirumuskan sebagai kecenderungan pendirian keagamaan seseorang dalam melihat dan menanggapi isu-isu sosialkeagamaan yang ada. Studi ini menggunakan kombinasi teori-teori sosial dan keagamaan (sosial-teologis) untuk menjelaskan fenomena sikap keagamaan di atas. Survei ini berhipotesis bahwa model paham, sikap, dan perilaku keagamaan warganya bervariasi menurut latar belakang agama. Di sini, kesadaran, pendirian dan pengalaman keagamaan, kondisi sosialekonomi-kultural-politik dan psikologis seseorang diteoritisasikan membentuk gaya sikap dan perilakunya untuk memaknai fakta dalam berinteraksi dengan orang lain dalam bingkai agama. Meskipun pengaruh yang muncul tidak deterministik, dan satu-arah, namun di sana selalu terdapat relasi yang cenderung kompleks antara kondisi sosial-keagamaan suatu daerah dengan sikap dan perilaku penghuninya.

Kenapa harus pendidikan tinggi agama yang disorot di sini? Karena pendidikan tinggi adalah media penting untuk menapaki jenjang mobilitas sosial. Rangkaian penelitian sosial secara konsisten menemukan fakta bahwa variabel pendidikan menjadi faktor terpenting untuk percepatan mobilitas, perbaikan status sosial, sekaligus membentuk sikap-perilaku sosial-keagamaan seseorang. ${ }^{6}$ Di Indonesia, banyak perguruan tinggi yang secara khusus mengajarkan agama dan ilmu agama. Pendidikan dan pengajaran agama model ini bertujuan rangkap untuk mendidik calon sarjana agama yang intelek, berwawasan keagamaan yang holistik, dan sekaligus diharapkan menjadi pemuka agama yang berkualitas untuk menjadi figur teladan dalam kehidupan beragama.

Fenomena seperti ini tidak hanya muncul di kalangan umat Islam, tetapi juga semarak di komunitas non Muslim. Via kebijakan pemerintah, setiap agama memiliki PTA negeri yang secara khusus mendidik calon sarjana agama. Di sini kehadiran PTA, dalam perkembangannya, menjadi gerbang misionaris (dakwah) untuk menyemai nilai-nilai luhur agama, dan pemusatan pembinaan persiapan para tokoh agama yang dibutuhkan di setiap komunitas agama. PTA sebagai lembaga pendidikan tinggi, dalamkonteksini, memainkan peranan strategis dan krusial dalam mendidik calon lulusan yang siap melayani hajat publik

${ }^{6}$ David B. Grusky. 1994. Social Stratification: Class, Race, and Gender in Sociological Perspective, Boulder, Colorado: Westview Press Inc.; Iwan G. Sujatmiko. 1996. "Stratifikasi Sosial dan Mobilitas Sosial”, Jurnal Sosiologi Indonesia, No. 1. 
umat beragama. Di tangan mereka, masa depan umat diamanatkan. Secara sosiologis, watak ramah-bengis, dan santun-kasar umat sangat ditentukan oleh model pembinaan keagamaan yang diturunkan dari pemuka agamanya.

Dalam konteks peranan PTA ini, jika gaya beragama dan aksi radikal berwajah agama semarak terjadi di kalangan mahasiswa PTA, pada gilirannya, gejala ini dapat merambat, merasuki kesadaran masyarakat awam via pembinaan pemuka agamanya.

Akhir-akhir ini, kampus yang berbasisberasosiasi pada organisasi agama tertentu sulit menutup diri dari kehadiran calon mahasiswa dengan beragam latar belakang. Jika dulu, kampus PTA Islam, umpama, cenderung disesaki oleh mahasiswa yang berbasis pesantren, saat ini, PTA Islam (karena sebagian mengalami transformasi menjadi universitas) sudah diserbu calon mahasiswa dengan beragam latar belakang. Suasana kesyahduan sentuhan yang religius, ramah, santun dan toleran mulai meredup, dan pada saat bersamaan mulai tumbuh tidak terbendung kegelisahan terhadap fenomena sekularisasi, dan despritualisasi atmosfer kampus di kalangan kelompok tertentu. Kesadaran ini menjadi lahan subur untuk tumbuh berkembang potensi kesadaran keagamaan radikal, eksklusif sebagai reaksi terhadap kondisi kampus yang cenderung sekuler.

Teori berbasis ilmu keagamaan menegaskan bahwa sikap dan perilaku keagamaan adalah fungsi dari faktor-faktor internal keagamaan. Anasir terakhir ini dalam bingkai model beragama secara konseptual dipilah menjadi (1) klaim absolutisme kebenaran agama, (2) model eksklusivisme teologi beragama, (3) inklusivisme sosial beragama, dan (4) dukungan terhadap wacana positivisasi ajaran agama.

Konstruksi keempat variabel di atas dan sikap keagamaan radikal (yang rinciannya dijelaskan belakangan) dilakukan dengan menggunakan analisis faktor. Loading factor variabel tersebut di atas di $65 \%$ dengan tingkat
KMO > 0.7. masing-masing faktor terdiri atas sejumlah indikator dengan tingkat validitas $r$ $>0.4$ dan tingkat reliabilitas $>0.7$. Faktor klaim absolut kebenaran agama diukur dengan 7 indikator, yaitu (1) Ketuntasan ajaran Kitab Suci agama responden untuk menjawab kebutuhan rohani-spritual setiap orang; (2) Kesempurnaan ajaran agama untuk menjawab semua problem kehidupan umat manusia; (3) Jalan keselamatan hidup (dunia-akhirat) hanya terdapat dalam agama responden; (4) Hanya ajaran agama responden yang dapat mewujudkan keadilan; (5) Dunia akan damai jika semua orang menganut agama responden; (6) Hanya ajaran agama responden yang mengajarkan cara berhubungan (beribadat) dengan Tuhan; dan (7) Berdoa/beribadat yang tidak mengikuti tatacara yang diajarkan agama responden tidak akan dikabulkan Tuhan.

Faktor eksklusivisme pendirian teologi beragama diukur dengan 4 indikator, yaitu (1) Kesesatan tafsir-paham keagamaan yang berbeda dengan standar tafsir mayoritas; (2) Kesesatan semua orang yang seagama dengan responden, tetapi tidak sealiran, tidak semazhab dengan paham/mazhab keagamaannya; (3) Balas dendam pada pihak yang telah menyerang kehormatan agama adalah satu perintah agama; dan (4) Penodaan-penghinaan terhadap ajaran agama harus dilawan dengan aksi kekerasan.

Faktor inklusivisme sosial beragama diukur dengan 5 indikator, yaitu (1) Kesiapan menerima tamu agama lain membaur hadir di acara umum/bukan kegiatan agama; (2) Keberatan jika tetangga yang tak seiman mengadakan ritual keagamaan di rumah sendiri dengan mengundang jemaat luar; (3) Keberatan menyewakan aset pribadi (rumah/ toko) pada umat agama lain; (4) Keberatan jika umat lain memasuki tempat ibadat agama responden walaupun dengan cara yang sopan; dan (5) Kesiapan meminjamkan perabot rumah tangga (seperti kursi, tikar, karpet, sepeda, selain alat makan) pada umat lain. 
Terakhir, dukungan terhadap wacana positivisasi norma agama diukur dengan 5 indikator, yaitu (1) Keharusan ajaran agama responden diberlakukan sebagai hukum nasional (hukum positif) Indonesia; (2) Persetujuan terhadap pemberlakuan hukum agama terhadap pelaku zina (praktek seks di luar nikah); (3) Restu terhadap gerakan keagamaan garis keras untuk menegakkan ajaran agama; (4) Restu terhadap hukuman potong tangan bagi para pencuri di Indonesia; dan (5) Kecenderungan memilih partai berbasis agama dalam pemilihan umum.

Faktor internal ini menjadi satu prakondisi kesadaran teologis, hulu dari sikap dan perilaku keagamaan, Prakondisi ini akan siap mewujud nyata baik secara sporadis, gradual, dan dapat sistematis, secara sopan dan beradab, tetapi bisa juga meledak sangat dahsyat menjadi satu ekspresi yang menggemparkan. Prakondisi kejiwaan keagamaan, keyakinan dan pendirian ekslusivisme teologis dihipotesiskan sebagai faktor independen yang memicu, memupuk, dan melegitimasi segala potensi sikap dan perilaku keagamaan radikal dalam menyikapi segala realitas hidup.

Sementara itu beragama radikal dalam studi ini diartikan sebagai pandangan yang ingin melakukan perubahan yang mendasar sesuai dengan interpretasi agama terhadap realitas tertentu (sosial-ekonomi-politik atau ideologi). Ia muncul dan berkembang sebagai sebuah tanggapan terhadap kondisi yang sedang berlangsung. Tanggapan ini umumnya sebagai wujud dari evaluasi, penolakan atau bahkan perlawanan. Penolakan ini tidak hanya berhenti secara pasif, tetapi ia berlanjut dalam wujud perlawanan frontal, bawah tanah untuk mengubah tatanan lama sampai ke akarakarnya dengan suatu bentuk tatanan baru. Model beragama radikal selalu didasarkan pada keyakinan ideologis yang kuat terhadap sesuatu yang didukungnya. ${ }^{7}$

${ }^{7}$ Horace M. Kallen. 1972. "Radicalism" dalam Edwin R.A. Selligman, Encyclopedia of the Social Sciences, Vol. XIIIXIV. New York: The McMillan Company. hal.51-54.
Radikal dan radikalisme, sebenarnya, adalah konsep yang netral, tidak berkonotasi pejoratif (melecehkan), dan juga tidak bermakna negatif. ${ }^{8}$ Perubahan radikal, sesungguhnya, dapat saja dicapai via medium elegan yang damai, ramah, santun dan persuasif, tetapi ia bisa juga digapai dengan cara dan aksi kekerasan, licik dan vulgar. Namun, belakangan, konsep radikalisme yang akrab dengan kekerasan, secara ekskusif, cenderung disematkan pada gerakan keagamaan tertentu, yang ajarannya berbasiskan pada paham skripturalisme, fundamentalisme dan puritanisme. 9

Kekerasan sebagai ekspresi radikalisme agama dapat mewujud dalam format yang beragam. Bentuk-bentuk kekerasan tersebut dapat saja bercorak teologis, psikologis, fisikal, sosial, dan politis, bahkan kekerasan dalam kerangka diskursus. ${ }^{10}$ Secara lebih spesifik dan teknis, terutama untuk studi ini, adalah perlu dibedakan antara kekerasan fisik dengan kekerasan non fisik, yang berbentuk simbolik-diskursif. Banyak pihak, biasanya secara ceroboh, mengasosiasikan kekerasan secara terbatas dengan aksi-aksi fisikal, seperti penyerangan, pemukulan dan pengrusakan. Cara pandangan ini terbukti mengabaikan fakta kekerasan simbolik-diskursif, psikologis. Ekspresi radikalisme, faktanya, dapat berwujud penistaan, penghinaan, penghujatan, cercaan, provokasi, labelisasi negatif, penyematan atribut eksklusif, dan stigmatisasi pada kelompok tertentu, dan/atau orasi yang bernada tendensius dan agitatif, termasuk hate speech,

8 Penulisan kerangka konseptual dan teoritis untuk perencanaan survei ini banyak merujuk pada basis kerangka penelitian SETARA Institute yang berjudul Radikalisme Agama di Jabodetabek dan Jawa Barat: Implikasinya terhadap Jaminan Kebebasan Keragaman/ Berkeyakinan, (Jakarta: Setara Institute, 2011). Namun demikian, pengayaan dan penajaman kerangka konseptual dan teoritis tetap dimaksimalisasi.

${ }^{9}$ Thaddeus Coreno. 2002 "Fundamentalism as a Class Culture", Sociology of Religion, Vol. 63, No. 3, hal. 335-6.

${ }^{10}$ Kevin O. Browne. 2001. Lanskap Hasrat dan Kekerasan, terj. Apri Danantor, et.al., Yogyakarta: Jendela bekerjasama dengan Yayasan Adikarya IKAPI dan The Ford Foundation. Thomas Santoso, ed. 2002. Teori-teori Kekerasan. Surabaya: PT. Ghalia Indonesia bekerjasama dengan Universitas Kristen Petra. 
dan condoning. Pencitraan kekerasan sebagai fenomena ekspresi entitas radikalisme sungguh mengabaikan kondisi faktual kekerasan non fisik tersebut, yang dalam dinamikanya sangat dimungkinkan mengalami puncak ekskalasi, berujung pada kekerasan fisik.

Konsep radikalisme keagamaan dalam studi ini dirumuskan sebagai bentuk pendirian, sikap dan perilaku radikal yang dipilah ke dalam 3 ranah, (1) keteguhan pendirian teologi radikal keagamaan, (2) apreasi terhadap politik radikal keagamaan, dan (3) dukungan terhadap penggunaan kekerasan untuk penegakan ajaran agama. Pertama, keteguhan pendirian teologi radikal keagamaan diukur dengan 4 indikator, yaitu (1) teror bom bunuh diri adalah satu bentuk perjuangan yang disahkan oleh agama; (2) selama untuk tujuan menegakkan agama, penggunaan kekerasan fisik dan senjata dapat dibenarkan; (3) kebanggaan terhadap para pelaku bom bunuh diri, karena mereka telah memperjuangkan agamanya; dan (4) Imam Samudra, Amrozi, Noordin M. Top dan Osama bin Laden adalah contoh orang yang mempraktekan jihad sejati dalam Islam (dua indikator terakhir ini hanya ditanyakan pada responden muslim).

Kedua, politik radikal keagamaan diukur dengan 4 indikator, yaitu (1) hidup mati setiap umat bera-gama harus membela kebenaran agama, walaupun harus dengan mengorbankan nyawa; (2) penolakan terhadap rencana anggota keluarga dekat untuk menikah dengan umat agama lain; (3) melakukan perlawanan terhadap kelompok lain yang menghalangi pelaksanaan ajaran agama; dan (4) menolak keberadaan guru agama lain mengajar di sekolah yang mayoritas siswanya tidak seagama dengannya.

Faktor dukungan terhadap penggunaan kekerasan untuk penegakan ajaran agama diukur dengan 5 indikator, yaitu (1) setiap umat beragama harus menolak segala gagasan yang mengajarkan paham liberal (tafsir bebas) dalam memahami ajaran; (2) kesiapan mati untuk membela kepentingan agama yang dianut; (3) aksi teror bisa dibenarkan saat jalan persuasif (damai) sudah tidak ada lagi untuk mencapai tujuan agama; (4) kecenderungan memilih calon kepala daerah (Bupati-walikota) yang tidak seagama; dan (5) keberatan bekerja dengan atasan (bos) yang tidak seagama.

\section{HASIL DAN PEMBAHASAN}

\section{Profil Responden}

Berikut beberapa profil responden dari studi yang menjadi dasar penulisan makalah ini. Secara keseluruhan, proporsi responden menurut jenis kelamin sangat seimbang. Responden Islam dan Buddha lebih banyak laki-laki, sedangkan responden lainnya lebih banyak perempuan. Mayoritas responden non Buddha berasal dari PTA negeri, dan seluruh responden Katolik berasal dari PTA swasta, karena umat Katolik belum memiliki PTA negeri. Satu hal yang menarik bahwa sesuai dengan pengakuan, berkisar $2 \%$ responden memeluk agama non bawaan lahir, terutama non muslim.

Responden non muslim, umumnya, berlatar pendidikan SLTA non keagamaan. Sebaliknya, lebih dari separoh responden Islam berasal dari SLTA agama; mayoritas responden muslim, Protestan dan Hindu, mengaku sebagai mayoritas di atas $70 \%$ pada komunitasnya. Sementara itu, lebih dari separoh responden masih kuliah maksimal di tahun kedua. Pengalaman responden dalam hal ekspose pada variasi suku dan agama masih relatif rendah. Mayoritas responden Hindu tidak pernah tinggal serumah dengan kolega yang berasal dari luar sukunya. Sebaliknya, pengalaman responden muslim dan Katolik cukup menarik, dimana rata-rata satu dari 3 orang responden pernah tinggal serumah dengan orang yang berbeda suku.

Ekspose pada keragaman latar belakang agama cukup merata. Mayoritas responden kecuali Katolik dan Buddha tidak pernah serumah dengan orang yang berbeda agama. 
Dengan kata lain, homogenitas asal-usul responden relatif tinggi. Fakta ini mengisyaratkan bahwa responden umumnya berasal dari komunitas mayoritas di daerah tempat asalnya. Data latar belakang sosial-demografis ini diharapkan dapat memberi satu informasi awal untuk memahami hasil studi ini.

\section{Model Pemahaman Keagamaan-Klaim Absolutisme Kebenaran Agama}

Tabel 1 berikut ini menyajikan ringkasan statistik temuan penelitian. Butir 1 Tabel ini menyajikan data tentang klaim absolutisme kebenaran agama. Klaim absolutisme direntang dari score 1 untuk menilai tingkat paling rendah penerimaan absolutisme kebenaran agama, sampai level 100 (score maksimal absolutisme kebe-naran agama). Semakin tinggi score yang ditunjukkan, maka semakin tinggi tingkat klaim absolutisme yang dipegang teguh seseorang responden. ${ }^{11}$

Tabel 1:

Ringkasan Model Pendirian Keagamaan (mean dengan skala 1-100)

\begin{tabular}{|l|c|c|c|c|c|c|}
\hline $\begin{array}{l}\text { Faktor } \\
\text { Pendirian } \\
\text { Keagamaan }\end{array}$ & Islam & Katolik & Kristen & Hindu & Buddha & Variance \\
\hline $\begin{array}{l}\text { Klaim } \\
\text { Absolutisme } \\
\text { Kebenaran } \\
\text { Agama }\end{array}$ & 79 & 34 & 50 & 47 & 20 & p.<.01 \\
$\begin{array}{l}\text { Eksklusivisme } \\
\text { Pendirian } \\
\text { Teologis }\end{array}$ & 43 & 24 & 28 & 22 & 18 & p.<.01 \\
$\begin{array}{l}\text { Inklusivisme di } \\
\text { Ranah Sosial- } \\
\text { Keagamaan }\end{array}$ & 76 & 71 & 72 & 72 & 72 & TS \\
$\begin{array}{l}\text { Dukungan } \\
\text { terhadap } \\
\text { Positivisasi } \\
\text { Hukum Agama }\end{array}$ & 47 & 34 & 39 & 32 & 30 & p.<.0. \\
\hline
\end{tabular}

Sumber: Diolah dari data lapangan

Tingkat klaim abolutisme kebenaran agama di kalangan mahasiswa PTA mencapai 66 point untuk semua responden lintas agama. Responden muslim memiliki level klaim absolutisme tertinggi (79)

11 Klaim absolutisme dalam kajian psikologi agama disebut juga dogmatisme. yang cenderung merata, sedang responden Buddha memperlihatkan level yang paling rendah (20). Namun, dalam konteks ini, di kalangan responden Buddha terjadi polarisasi yang diperlihatkan oleh data standar deviasi yang tinggi. Temuan ini mengisyaratkan bahwa di kalangan mahasiswa Buddha, ada komunitas yang sangat meyakini absolutisme agama, sebaliknya, ada di antara mereka yang sangat terbuka terhadap relativisme kebenaran agama. Uji variance membuktikan bahwa tingkat klaim absolutisme kebenaran bervaraiasi secara signifikan menurut agama. Uji statistik ini mengisyaratkan bahwa mahasiswa dengan variasi latar belakang agama memiliki perbedaan level klaim absolutism kebenaran ajaran agama.

Secara keseluruhan bisa ditegaskan bahwa tingkat keyakinan responden terhadap absolutisme kebenaran agama relatif tinggi. Fakta ini tidak harus dimaknai negatif mengingat kebenaran unsur-unsur teologis, seperti prinsip keimanan, memang harus diyakini secara absolut, hitam-putih oleh penganutnya. Bahkan keteguhan pendirian teologis terhadap absolutisme kebenaran ini sebuah keharusan iman, agar setiap pemeluk tidak dilanda keraguan terhadap eksistensi ajaran agamanya. Dalam konteks seperti ini, setiap agama selalu mengajarkan prinsip keteguhan iman ke dalam hati sanubari pemeluknya. Bahkan dalam Islam, tidak ada toleransi dalam hal keyakinan dan pendirian teologis.

Namun keteguhan keyakinan terhadap absolutisme kebenaran agama seperti pisau bermata ganda; positif dan negatif. Dari sisi negatif, jika responden tidak mampu mengelola klaim absolutisme kebenaran dengan benar dan bijak, ia dapat menjebak penganutnya dalam lilitan dogmatisme yang dapat dan akan menggiring individu yang bersangkutan bersikap dan bertindak vulgar, intoleran, tanpa kompromi saat menyikapi segala hal yang bersinggungan dengan klaim kebenaran absolut tersebut. Masalah ini penting mengingat dogmatisme bisa berfungsi laten sebagai kondisi kejiwaan awal yang akan mengantarkan 
seseorang bersikap apatis terhadap klaim kebenaran dari pihak lain, atau kecenderungan berpikir "hitam-putih" ala agama dalam menyikapi segala persoalan.

\section{Model Eksklusivisme Pendirian Teologis}

Butir 2 Tabel di atas menyajikan datatentang eksklusivisme pendirian teologis. Berdasarkan data pada Tabel 2, level eksklusivisme pendirian teologis responden relatif moderat, hanya berkisar 37 dari nilai maksimal 100. Secara detail, responden muslim memperlihatkan sikap eksklusivisme teologis yang paling tinggi (43). Satu hal yang penting untuk dicatat bahwa standar deviasi untuk setiap agama relatif tinggi, yaitu di atas 50 persen dari nilai rata-rata. Data statistik ini mengisyaratkan bahwa ada variasi eksklusivisme pendirian teologis yang cukup melebar di kalangan responden. Artinya, ada banyak mahasiswa PTA yang cenderung bersikap sangat eksklusif terhadap hal-hal prinsip fundamental keagamaan, sebaliknya, ada individu yang cenderung bersikap sangat toleran terhadap keragaman pendirian teologis ini. Dengan kata lain, data studi ini memperlihatkan tingkat variasi sikap eksklusivisme yang cukup signifikan di kalangan mahasiswa PTA lintas agama. Variasi ini cukup strategis dan relevan untuk mengkritisi lebih jauh pengaruh faktor sikap eksklusivisme beragama ini terhadap potensi radikalisme mahasiswa PTA.

\section{Model Inklusivisme Beragama di Ranah Sosial-Keagamaan}

Merujuk data pada butir 3 Tabel di atas, gaya inklusif beragama mahasiswa PTA di ranah kehidupan bermasyarakat cukup baik, cukup tinggi, mencapai 74 point. Satu Hal yang menarik bahwa responden muslim memiliki tingkat inklusivisme beragama di ranah sosialkeagamaan yang paling tinggi, di atas standar rata-rata lintas agama; sedang standar deviasi untuk variabel sikap inklusivisme cukup kecil. Data ini mengisyaratkan bahwa inklusivisme beragama di ranah sosial-keagamaan relatif merata di kalangan mahasiswa PTA, kecuali mahasiswa muslim. Secara tentatif dapat disimpulkan bahwa sikap eksklusif di ranah kehidupan sosial bukan menjadi watak utama dari sikap sosial-keagamaan mahasiswa PTA. Namun, benih ekskluvisme sosial-keagamaan masih tetap melekat laten, terpendam jauh di alam bawah sadar sejumlah mahasiswa dalam wujud eksklusivisme pendirian teologi. Ini artinya bahwa masih ada sekelompok mahasiswa PTA yang cenderung menurut diri dari interaksi dengan pemeluk agama lain.

\section{Dukungan Terhadap Positivisasi Hukum Agama Di Ranah Publik}

Banyak orang tidak sependapat bahwa isu agama adalah masalah privat, yang tabu untuk ditarik ke ranah publik, apalagi memasuki ranah politik. Kelompok aktivis agama politik, sebaliknya, menghendaki positivisasi hukum agama dalam kancah kenegaraan. Bahkan di tanah air ini, semangat untuk mendirikan negara agama masih sering terdengar, seperti gerakan NII. Seperti apa semangat positivisasi hukum agama di kalangan mahasiswa PTA?

Butir 4 Tabel 1 di atas menyajikan data tentang level dukungan terhadap wacana positiviasi hukum agama di ranah politik bernegara. Di sini, semangat dukungan terhadap positivisasi hukum agama dalam kehidupan publik cukup tinggi, mencapai 42 point. Responden muslim, terutama memperlihatkan semangat tertinggi untuk etos positivisasi hukum agama di ranah publik. Temuan ini tidak mengagetkan, mengingat sejumlah penelitian lain juga menemukan fenomena yang senada, yaitu keinginan dan dukungan sektarian terhadap usaha positiviasi hukum agama, terutama di kalangan muslim. Fakta ini mengingatkan kita bahwa semangat untuk menjadikan hukum agama sebagai hukum nasional masih cukup tinggi di kalangan mahasiswa PTA. 
Potensi Radikalisme Agama di Kalangan Mahasiswa PTA

Fenomena gaya beragama radikal bukan sebuah ilusi. Teror bom bunuh diri dan penyerangan terhadap fasilitas dan organisasi paham keagamaan minoritas lumrah terjadi. Pelaku utamanya adalah anak muda, seusia dengan mayoritas mahasiswa stratum 1. Bagaimana kecenderungan sikap radikalisme di kalangan mahasiswa PTA?

Tabel 2:

Model Pendirian Keagamaan Radikal (mean dengan skala 1-100)

\begin{tabular}{|l|c|c|c|c|c|c|}
\hline $\begin{array}{l}\text { Faktor Pendirian } \\
\text { Keagamaan } \\
\text { Radikal }\end{array}$ & Islam & Katolik & Kristen & Hindu & Buddha & Variance \\
\hline $\begin{array}{l}\text { Keteguhan } \\
\text { Pendirian } \\
\text { Teologi Radikal }\end{array}$ & 29 & 17 & 16 & 19 & 13 & $p .<.01$ \\
\hline $\begin{array}{l}\text { Politik radikal } \\
\text { keagamaan }\end{array}$ & 70 & 52 & 45 & 55 & 41 & $p .<.01$ \\
\hdashline $\begin{array}{l}\text { Dukungan } \\
\text { instrumentasi } \\
\text { kekerasan untuk } \\
\text { penegakan } \\
\text { ajaran agama }\end{array}$ & 64 & 36 & 38 & 44 & 32 & $p .<.01$ \\
\hline
\end{tabular}

Sumber: Diolah dari data lapangan

Tabel 2 di atas menyajikan data tentang potensi sikap radikalisme agama. Pada studi ini, konsep radikalisme dianalisis menurut rumpun dimensi-dimensinya. Mengacu pada hasil analisis faktor (factorial analysis), radikalisme dipilah menjadi tiga faktor, dan ketiganya bersifat mandiri; satu dimensi bersifat eksklusif dari dimensi lain, atau ia tidak menjadi bagian dari dimensi lainnya, yaitu keteguhan pendirian teologi radikal keagamaan, sikap politik radikal keagamaan, dan dukungan terhadap instrumentasi dan strategi berbasis kekerasan untuk penegakan ajaran agama. Dimensi pertama untuk memotret tingkat potensi (basis) pendirian teologi radikalisme. Dimensi kedua untuk memotret pendirian politik (gerakan) keagamaan radikal. Dimensi terakhir dimaksudkan untuk melihat strategi dan metodologi politik gerakan radikal.
Dengan pemilahan dimaksud dan sesuai dengan analisis faktor, hasil analisis ini diharapkan dapat memberi legitimasi akademis dan gambaran empiris yang lebih utuh dan spesifik tentang gejala potensi radikalisme di kalangan mahasiswa PTA menurut ranahnya masingmasing.

Jika rentang kontinum potensi radikalisme dipilah menjadi empat kategori, maka deskripsi pemaknaannya sebagai berikut. Level pertama (kuartil 1) mengisyaratkan bahwa potensi radikalisme agama masih mengendap laten dalam kesadaran keteguhan pendirian teologi umat beragama dalam kehidupan personal keagamaan seseorang. Ranah pertama ini menjadi basis sikap kecederungan seseorang untuk perilaku radikal yang lebih aktual dan vulgar. Level kedua (kuartil 2) memasuki ranah sikap strategis untuk aktualisasi pesanpesan agama. Level ini ditandai dengan watak kecenderungan individu umat beragama untuk mengidealisasikan ajaran agamanya sebagai satu media penyelesaian problem sosial, ekonomi dan politik. Level ini ditandai dengan dukungan terhadap wacana positivisasi ajaranhukum agama.

Level ketiga (kuartil 3) adalah ranah kecenderungan bertindak yang lebih bersifat kondisional, rasional dan agak pragmatis. Sikap nekad belum menggejala pada level ketiga ini. Level terakhir (kuartil 4) adalah radikalisme yang mengarah pada perilaku keagamaan yang nekad dengan beragam manifestasi kekerasan, yang puncaknya adalah teror bom bunuh diri dan penyerangan terhadap kelompok yang dinilai berseberangan dengan paham keagamaannya.

\section{Keteguhan Pendirian Teologi Radikal Keagamaan}

Butir 1 Tabel 2 menyajikan data tentang keteguhan pendirian teologi radikal keagamaan. Tingkat keteguhan pendirian teologi radikalisme mahasiswa PTA masih relatif tergolong rendah, di level pertama 
(25 point). Namun, angka-angka statistik ini mengingatkan bahwa fenomena keteguhan sikap teologi radikal bisa menjadi potensi bom waktu radikalisme yang siap meledak kapan saja, saat ia menemukan momentum pemicu yang kondusif. Walaupun rendah, namun secara teoritis, basis keteguhan pendirian teologi radikal bisa mengalami eskalasi jika ia didorong oleh sejumlah faktor.

Ada satu hal yang menarik untuk dicermati lebih kritis dari data pada butir 1 di atas. Angka standar deviasi kecenderungan teologi radikal keagamaan sangat tinggi lintas agama, yaitu melebihi level 50 persen dari angka rata-rata $($ mean $=25)$. Statistik ini mengisyaratkan bahwa ada komunitas mahasiswa PTA yang memiliki tingkat keteguhan pendirian teologi radikalisme yang super ekstrim dan ada yang sangat moderat. Artinya, ada variasi yang sangat menyolok dalam hal kecenderungan teologi radikal keagamaan di kalangan mahasiswa PTA.

Secara keseluruhan, apapun agama yang dianut responden, gejala keteguhan pendirian teologis radikal ini tetap eksis, laten dan emanen dalam jiwa dan pendirian teologi penganutnya, walaupun dalam skala yang relatif rendah. Aspek ini harus diperhatikan oleh para pemangku kebijakan pembinaan pendidikan di PTA, terutama untuk suatu kepentingan peringatan diri (early warning system) tentang tantangan radikalisme agama di kalangan mahasiswa PTA.

\section{Politik Radikal Keagamaan}

Butir 2 Tabel 2 menyajikan data tentang pendirian politik radikal keagamaan. Jika ranah pertama baru menyentuh level kesadaran teologis, ranah kedua ini sudah memasuki wilayah semangat radikalisme yang lebih lebih nyata. Pada konteks ini, kecenderungan untuk bersikap dan bertindak radikal menjadi lebih aktual dalam kehidupan beragama. Bagaimana potensi politik radikalisme agama mahasiswa PTA?
Merujuk Butir 2 Tabel 2 di atas, ada satu hal yang penting untuk digaris-bawahi di sini bahwa potensi radikalisme di ranah gerakan politik praktis keagamaan nampak relatif tinggi, menyentuh angka di atas 60 point dari score maksimal 100. Perlu ditegaskan ulang bahwa semakin tinggi pendirian politik radikal keagamaan, semakin potensial seseorang untuk bersikap dan bertindak radikal.

Data ini mengingatkan kita bahwa potensi radikalisme di ranah kesadaran strategi politik gerakan keagamaan mahasiswa PTA harus mendapat perhatian khusus. Secara konsisten, data statistik mengingatkan bahwa tingkat potensi radikalisme agama untuk dimensi kedua ini bervariasi menurut faktor agama. Satu hal yang masih perlu dicermati secara khusus adalah apakah variabel agama dengan model doktrin teologisnya yang berbeda menjadi faktor penting, signifikan dalam membentuk kecenderungan sikap dan bertindak radikal. Hasil uji varian yang dilakukan secara terpisah membuktikan bahwa variabel afiliasi agama menjadi faktor determinan yang sangat sangat signifikan (p. <.01) dalam konstruksi kecenderungan bertindak bersikap dan bertindak radikal dimaksud.

\section{Dukungan terhadap Instrumentasi Kekerasan untuk Realisasi Pesan Agama}

Butir 3 Tabel 2 di atas menyajikan data tentang sikap dukungan mahasiswa PTA terhadap penggunaan media kekerasan untuk aktualisasi pesan agama. Satu hal yang unik dan sekaligus menarik bahwa mahasiswa PTA masih cenderung toleran, dan dapat menerima (55 point) penggunaan media kekeasaran untuk usaha dan proses aktualisasi, pembelaan dan penegakan ajaran agama yang dianutnya. Tingkat kecenderungan sikap dukungan terhadap penggunaan media kekerasan juga cukup bervariasi menurut faktor agama.

Fenomena dukungan terhadap penggunaan media kekerasan ini atas nama agama, semakin menguat untuk dua 
indikator utama yang lumrah dipakai dalam sejumlah penelitian untuk mengukur tingkat radikalisme. Dukungan cukup tinggi terhadap pembenaran "pembenaran penggunaan aksi teror saat jalan persuasif sudah tidak ada lagi untuk mencapai tujuan agama", dan "kesiapan mati untuk membela kepentingan agama”, di atas 50 point. Dengan kata lain, potensi bersikap dan bertindak radikal dalam wujud dukungan terhadap semangat penggunaan kekerasan untuk mencapai target kepentingan agama masih cukup kental dan membatin kuat di kalangan mahasiswa PTA dan juga pada dimensi keteguhan pendirian teologis, serta strategi gerakan politik radikal keagamaan.

\section{Wujud Ekspresi Radikalisme Keagamaan}

Radikalisme agama bukan sebatas wacana dan potensi di level praksis, tetapi ia sudah menjadi satu tontonan publik. Bagaimana wujud ekspresi radikalisme agama di kalangan mahasiswa PTA? Beberapa tabel berikut menampilkan bentuk ekspresi radikalisme dimaksud, yang dipilah menjadi ekspresi behaviral (tindakan), dan dalam wujud rencana aksi radikal atas nama agama.

Tabel 3:

Pengalaman Merencanakan/Melakukan Sweeping tempat yang dianggap bertentangan dengan ajaran agama (\%)

\begin{tabular}{|l|c|c|c|c|c|}
\hline $\begin{array}{l}\text { Faktor Pendirian } \\
\text { Keagamaan }\end{array}$ & Islam & Katolik & Kristen & Hindu & Buddha \\
\hline Tidak Pernah & 90.2 & 92 & 96.5 & 93.9 & 100 \\
\hline Pernah & 8 & 5.3 & 2.4 & 3.1 & 0 \\
\hline Tidak menjawab & 1.8 & 2.7 & 1.2 & 3 & 0 \\
\hdashline$N$ & 480 & 70 & 83 & 64 & 54 \\
\hline
\end{tabular}
Sumber: Diolah dari data lapangan

Tabel 3 menyajikan informasi tentang pengalaman responden terlibat dalam merencanakan dan/atau melakukan aksi sweeping atau razia tempat-tempat yang dianggap bertentangan dengan ajaran agama (seperti tempat judi dan pelacuran) menurut basis agama. Ekspresi radikalisme dalam wujud pertama ini tidak akrab dalam tradisi mahasiswa PTA. Hanya sebagian kecil responden Muslim, Kristiani dan Hindu yang pernah ikut terlibat dalam perencanaan dan/ atau tindakan sweeping atau razia tempat yang dianggap bertentangan dengan ajaran agama. Responden muslim dan Katolik paling dominan di antara responden yang mengaku pernah terlibat dalam aksi dan rencana sweeping. Sebaliknya, aksi sweeping ini tidak dikenal dalam tradisi dan praktek sosial-keagamaan responden Buddha.

Aksi kekerasan atas nama agama bisa belum terjadi karena ketiadaan faktor pemicu. Jika responden mahasiswa PTA belum pernah melakukan sweeping, apakah mereka akan ikut terlibat sweeping jika mereka mendapat kesempatan yang kondusif dan menguntungkan? Satu hal yang menarik dari data pada Tabel 4 di atas bahwa potensi keterlibatan dalam aksi radikal dalam wujud perencanaan atau pelaksanaan sweeping tempat yang dianggap bertentangan dengan ajaran agama masih relatif cukup potensial. Minimal sekitar 20 persen responden, lintas agama, mengatakan bahwa mereka masih berniat untuk terlibat dalam aksi di atas. Di kalangan mahasiswa PTA Islam, potensi ekspresi dalam wujud kesediaan terlibat dalam aksi sweeping dua kali lebih tinggi dibanding dengan potensi yang sama di kalangan mahasiswa non Islam. Ini artinya bahwa fenomena ekspresi radikal lebih dekat dengan tradisi perilaku beragama mahasiswa muslim, jika dibanding dengan umat agama lain.

Tabel 4:

Kesediaan Ikut Razia/Sweeping Bila Ada Kesempatan (\%)

\begin{tabular}{|l|c|c|c|c|c|}
\hline $\begin{array}{l}\text { Faktor Pendirian } \\
\text { Keagamaan }\end{array}$ & Islam & Katolik & Kristen & Hindu & Buddha \\
\hline Tidak Berminat & 21 & 52 & 45 & 41 & 56 \\
\hdashline Belum terpikirkan & 39 & 24 & 34 & 35 & 26 \\
\hdashline Mungkin ikut & 28 & 11 & 9 & 15 & 11 \\
\hline Pasti ikut & 8 & 7 & 7 & 5 & 6 \\
\hline Tidak menjawab & 4 & 7 & 5 & 6 & 2 \\
\hdashline N & 480 & 70 & 83 & 64 & 54 \\
\hline
\end{tabular}


Ekspresi radikalisme dalam studi ini juga dipotret dalam wujud aksi demontrasi terhadap kelompokyang dinilai menodai atau mengancam kesucian agama. Seperti gejala pada Tabel sebelumnya, aksi demonstrasi memprotes kelompok yang dinilai menyimpang (Tabel 5) juga tidak begitu menggejala di kalangan mahasiswa PTA. Namun, frekuensi ekspresinya lebih besar dibanding dengan ekspresi radikal dalam bentuk sweeping/razia. Satu hal yang menarik di sini bahwa pengalaman terlibat dalam demonstrasi menentang kelompok yang dinilai menyimpang pernah dilakoni oleh semua mahasiswa lintas PTA, lintas agama. Ini artinya bahwa semangat dan aktualisasi ekspresi radikalisme agama dapat berpotensi untuk menjelma suatu saat, ketika ada suatu momentum yang memfalitasinya.

Tabel 5:

Pengalaman melakukan demonstrasi terhadap kelompok yang dinilai menodai atau mengancam kesucian agama (\%)

\begin{tabular}{|l|c|c|c|c|c|}
\hline $\begin{array}{l}\text { Faktor } \\
\text { Pendirian } \\
\text { Keagamaan }\end{array}$ & Islam & Katolik & Kristen & Hindu & Buddha \\
\hline Tidak Pernah & 84 & 80 & 94 & 75 & 93 \\
\hline $\begin{array}{l}\text { Pernah } \\
\text { Tidak }\end{array}$ & 15 & 15 & 6 & 25 & - \\
menjawab & 1 & 5 & 0 & 0 & 7 \\
\hline N & 480 & 70 & 83 & 64 & 54 \\
\hline
\end{tabular}

Sumber: Diolah dari data lapangan

Jika ekspresi radikal keagamaan hanya menunggu momentum yang kondusif, bagaimana kesediaan responden untuk terlibat dalam demonstrasi, jika suatu saat diajak, dan dia memiliki kesempatan untuk ikut terlibat dalam demonstrasi dimaksud? Tabel 6 menunjukkan bahwa kalangan responden Hindu, Katolik dan Islam memiliki niat yang lebih kuat (di atas 20\%) untuk terlibat dalam aksi demonstrasi tersebut jika mereka suatu saat diajak, dan memiliki kesempatan untuk ikut berpartisipasi. Dengan kata lain, fenomena demonstrasi anti tempat maksiat relatif potensial sekali untuk diikuti oleh mahasiswa
PTA Hindu, Katolik dan Islam. Gejala rendahnya semangat untuk berdemonstrasi sebetulnya agak aneh, mengingat dunia dan sikap kecenderungan mahasiswa nyaris identik dengan aksi demonstrasi menentang segala bentuk penyimpangan. Fenomena ini bisa saja dijadikan satu indikator bahwa mahasiswa lebih tertarik pada isu politik ketimbang isu-isu agama.

Tabel 6:

Jika tidak pernah, apakah responden bersedia ikut dalam aksi demonstrasi tersebut di atas bila ada kesempatan? (\%)

\begin{tabular}{|l|c|c|c|c|c|}
\hline $\begin{array}{l}\text { Faktor } \\
\text { Pendirian } \\
\text { Keagamaan }\end{array}$ & Islam & Katolik & Kristen & Hindu & Buddha \\
\hline $\begin{array}{l}\text { Tidak } \\
\text { Berminat }\end{array}$ & 24 & 56 & 57 & 43 & 67 \\
\hline $\begin{array}{l}\text { Belum } \\
\text { terpikirkan }\end{array}$ & 34 & 18 & 24 & 17 & 16 \\
\hdashline Mungkin ikut & 28 & 11 & 11 & 15 & 9 \\
\hline Pasti ikut & 10 & 12 & 5 & 18 & 6 \\
\hline $\begin{array}{l}\text { Tidak } \\
\text { menjawab }\end{array}$ & 4 & 3 & 4 & 7 & 2 \\
\hline N & 480 & 70 & 83 & 64 & 54 \\
\hline
\end{tabular}

Sumber: Diolah dari data lapangan

Gejala kekerasan atas nama terhadap kelompok agama dan paham keagamaan minoritas masih banyak terjadi. Berdasarkan Tabel 7, pengalaman responden mahasiswa PTA terlibat dalam aksi penyerangan terhadap kehadiran rumah ibadat umat lain sangat rendah. Responden dari PTA Hindu dan Protestan tidak pernah melakukan aksi dimaksud. Kalangan Islam (4.2 \%), Katolik (2.7 \%), dan Buddha (1.8 \%) dengan frekuensi yang agak berbeda, pernah, terlibat dalam aksi penyerangan tersebut. Secara keseluruhan, data ini mengisyaratkan bahwa aksi demonstrasi menolak tempat ibadat agama lain tidak terlalu menonjol. Ini artinya bahwa mahasiswa PTA relatif bisa menerima kenyataan kehadiran tempat ibadat agama lain. 
Tabel 7:

Pengalaman melakukan penyerangan/penolakan terhadap kehadiran rumah ibadat umat agama lain (\%)

\begin{tabular}{|l|c|c|c|c|c|}
\hline $\begin{array}{l}\text { Faktor Pendirian } \\
\text { Keagamaan }\end{array}$ & Islam & Katolik & Kristen & Hindu & Buddha \\
\hline Tidak Pernah & 95 & 96 & 100 & 100 & 98.2 \\
\hline Pernah & 4.2 & 2.7 & 0 & 0 & 1.8 \\
\hline Tidak menjawab & 0.8 & 1.3 & 0 & 0 & 0 \\
\hline N & 480 & 70 & 83 & 64 & 54 \\
\hline
\end{tabular}

Sumber: Diolah dari data lapangan

Terakhir, berdasarkan Tabel 8, kecenderungan minat untuk ikut terlibat dalam aksi penyerangan terhadap tempat ibadat agama lain juga sangat rendah. Ini sisi positif dari kedewasaan sosial beragama mahasiswa PTA dalam konteks kesediaan berdamaian dengan keberadaan tempat ibadat agama lain. Ringkasnya, wujud aksi radikalisme agama mahasiswa PTA masih sangat rendah, bahkan tidak perlu dirisaukan. Jika ada masih aksi radikalisme, fenomena ini hanya sebagai gejala geliat kelompok kecil mahasiswa yang memiliki ideologi dan sindrom eksklusivisme pendirian teologis, klaim absolutisme kebenaran agama, dan dukungan terhadap proyek positivisasi hukum agama.

Tabel 8:

Jika tidak pernah, apakah responden bersedia ikut dalam kegiatan tersebut

penyerangan dimaksud bila ada kesempatan?

\begin{tabular}{|l|c|c|c|c|c|}
\hline $\begin{array}{l}\text { Faktor Pendirian } \\
\text { Keagamaan }\end{array}$ & Islam & Katolik & Kristen & Hindu & Buddha \\
\hline Tidak Berminat & 62 & 81 & 85 & 87 & 93 \\
\hline Belum terpikirkan & 26 & 12 & 10 & 6 & 4 \\
\hline Mungkin ikut & 7 & 5 & 4 & 3 & 2 \\
\hline Pasti ikut & 1 & 1 & 1 & 2 & 0 \\
\hline Tidak menjawab & 4 & 1 & 0 & 2 & 1 \\
\hline N & 480 & 70 & 83 & 64 & 54 \\
\hline \multicolumn{2}{|l|}{ Sumber: Diolah dari data lapangan } \\
\hline
\end{tabular}

\section{PENUTUP}

\section{Kesimpulan}

Studi ini bermaksud menggali model sikap beragama dan potensi radikalisme agama di kalangan mahasiswa program strata 1 PTA (non Konghucu) dengan menggunakan pendekatan survei di 10 provinsi. Hasil studi memperlihatkan beberapa isu menarik dan perlu direfleksikan terutama dalam bingkai berpikir desain survei.

1. Mahasiswa PTA, sebagai intelektual muda, juga memiliki potensi kecenderungan keagamaan yang kompleks, dinamis, dan terkadang terjebak dalam ekstremintas kanan, radikal. Studi ini memperlihatkan bahwa fenomena gaya beragama eksklusif dan potensi radikalisme agama juga relatif akrab dengan kehidupan sosial-keagamaan mereka walaupun dengan intensitas yang tidak dominan.

2. Cara beragama sektarian dan eksklusif dalam pendirian teologi relatif dominan di kalangan mahasiswa PTA. Bahkan kecenderungan dukungan terhadap aksi dan wacana positivisasi norma agama juga masih mendapat tempat di hati mahasiswa PTA. Fenomena ini relatif merata di setiap komunitas agama. Temuan ini harus dikritisi lebih jauh seberapa gejala beragama ini berdampak langsung perilaku sosial keagamaan mahasiswa PTA interaksi lintas agama.

3. Secara umum, potensi radikalisme agama (keteguhan pendirian teologi radikal) masih tergolong rendah, di level pertama (25 points dari 100 points). Namun demikian, angka statistik ini mengingatkan bahwa pendirian keagamaan radikal dapat menjadi bom waktu yang siap meledak setiap saat, ketika ia tidak dikelola secara dini, tepat dan bijak, dan di sisi lain, ia menemukan momentum dan konteks pemicu yang kondusif untuk aktualisasinya.

4. Kecenderungan dukungan responden terhadap penggunaan media kekerasan untuk aktualisasi pesan-pesan agama masih relatif tinggi berkisar $32-44$ points, terutama responden muslim yang mencapai 64 points. Ringkasnya, Secara keseluruhan, responden mahasiswa PTA masih cenderung dapat menerima 
penggunaan media kekerasan untuk usaha dan proses aktualisasi, pembelaan dan penegakan ajaran agama.

5. Orientasi politik keagamaan radikal juga cukup tinggi, selalu di atas 50 points, kecuali untuk responden Protestan dan Buddha. Ini artinya bahwa potensi radikalisme di level pendirian teologis di atas mudah dapat tersalurkan menjadi sebuah teror atau tragedi, mengingat mesin politik keagamaan radikal cukup tinggi untuk menfasilitasi ledakan sikap teologis radikal.

6. Terlepas agama yang dianut responden, potensi dan fenomena radikalisme agama telah diperlihatkan nyata oleh sekelompok mahasiswa lintas agama. Perbedaannya hanya terletak pada aspek (1) model ekspresi instrumental (seperti aksi sweeping terhadap tempat-tempat yang dinilai melanggar norma agama), (2) basis ideologis (dukungan terhadap aksi keagamaan radikal), dan (3) intensitas aktivitasnya.

\section{Rekomendasi}

Berdasarkan analisis dan kesimpulan di atas, maka ada beberapa rekomendasi dan kebijakan untuk menyikapi model gaya beragama dan fenomena radikalisme di kalangan mahasiswa PTA.

1. Radikalisme adalah fenomena yang dekat dengan faktor-faktor internal umat beragama dalam hal keyakinan akan absolutisme kebenaran agama, tuntutan terhadap positivisasi dan institusionalisasi norma agama dalam kehidupan formal dan eksklusivisme pendirian teologis. Oleh sebab itu, program utama penanganan radikalisme agama yang sudah dirintis oleh sejumlah lembaga dan kalangan tidak boleh mengabaikan usaha deradikalisasi berbasis faktor internal keagamaan umat beragama.

2. Aspirasi positivisasi ajaran agama oleh komunitas penganut agama tertentu tidak boleh diabaikan. Proses dan program kanalisasi aspirasi ini, baik secara politis atau sosial, sedikit banyak akan dapat menuntun arah perjuangan kelompok radikal yang mengidealisasikan positivisasi hukum agamanya. Kenapa? karena kekecewaan yang memuncak terhadap pembiaran harapan mereka tersebut di ranah sosial dan politik, dapat memicu eskalasi ketegangan dan aktualisasi potensi radikalisme. Oleh sebab itu, satu pilihan yang bijak adalah program yang bisa mengakomodasi harapan kelompok tertentu yang berbasis ideologi keagamaan yang menghendaki agama ditarik ke ranah politik praktis, dan sekaligus.

3. Faktor ekspose mahasiswa terhadap keragaman paham keagamaan dan kelompok keagamaan di luar dirinya juga harus diperhatikan untuk menyikapi radikalisme agama mahasiswa PTA. Faktor terakhir ini sangat penting untuk dipertimbangkan guna memahami gejala radikalisme dalam kerangka dinamika sosial. Forum-forum komunikasi, dan interaksi lintas agama dan paham keagamaan, dapat menjembatani dan mengklarifikasi tunduhan sepihak dari kelompok keagamaan tertentu tentang sejumlah isu yang mereka nilai merugikan mereka. Ringkasnya, potensi radikalisme agama tidak dapat dibongkar habis, tetapi ia harus dikelola secara positif dan bijak, karena ia telah menyatu inheren dalam doktrin dan model keyakinan keagamaan.

4. Proses pendidikan keagamaan formal di level sekolah menengah dan perguruan tinggi juga harus mendapat perhatian. Pengenalan keragaman paham keagamaan ada baiknya dimulai sedini mungkin kepada para peserta didik. Di sisi lain, pendidikan agama yang lebih terbuka, rasional dan kritis di level perguruan tinggi harus lebih digalakkan. Pengajaran doktrin agama yang lebih inklusif, ramah, luas, dan menyeluruh juga harus diperhatikan, mengingat pembelajaran agama yang lebih utuh, terbuka, luas, dan kritis berpengaruh penting dalam konstruksi potensi radikalisme. 
5. Selain itu, figur pendidik agama di PTA, dan pergaulan sosial-keagamaan mahasiswa juga harus mendapat perhatian. Pengaruh dosen dan peer group sangat kuat dsi ini dalam pembentukan radikalisme agama. Hal ini semakin penting mengingat model kehidupan sosial-keagamaan masyarakat kita masih sangat paternalistik. Kekaguman kepada figur di atas (dosen, guru, tokoh agama, dan aktivisme agama) masih sangat kuat mempengaruhi sikap dan perilaku sosialkeagamaan masyarakat Indonesia.

\section{SUMBER BACAAN}

Azra, Azyumardi (2011): Kompas, 27 April. (1996). Pergolakan Politik Islam, Dari Fundamentalis, Modernisme hingga PostModernisme. Jakarta: Paramadina.

Bahri, Syamsul. (2004): "Islam dan Wacana Radikalisme Agama Kontemporer", Dinika, Vol. 3, No. 1.

Bakri, s., "Islam dan Wacana Radikalisme Agama Kontemporer", Dinika, Vol. 3, No. 1, (2004).

Dijk, C. Van. (1981): Rebellion under the Banner of Islam: Darul Islam in Indonesia. The Hague: Martinus Nijhoff.

Fealy, Greg, dan Anthony Bubalo. (2007): Jejak Kafilah: Pengaruh Radikalisme Timur Tengah Di Indonesia. Bandung: Mizan.

Grusky, David B. (1994): Social Stratification: Class, Race, and Gender in Sociological Perspective. Boulder, Colorado: Westview Press Inc.

Hasan, Noorhaidi. (2008): "Reformasi, Religious Diversity, and Islamic Radicalism after Suharto", Journal of Indonesian Social Sciences and Humanities, Vol. 1.; van Bruinessen, 'Genealogies of Islamic Radicalism in Post-Suharto Indonesia', South East Asian Research. Vol. 10. No. 2 (2002).

Hasan, Noorhaidi. (2006): Laskar Jihad: Islam, Militancy and the Quest for Identity in PostNew Order Indonesia. Ithaca, New York, SEAP Cornell University.
Hasani, Ismail, et.al. (2011): Radikalisme Agama di Jabodetabek dan Jawa Barat: Implikasinya terhadap Jaminan Kebebasan Keragaman/ Berkeyakinan. Jakarta, Setara Institute.

Jamhari dan Jajang Jahroni (Ed.). (2004): Gerakan Salafi Radikal Di Indonesia. Jakarta, Rajawali Pers.

LabSosio UI dan Puslitbang Penda Balitbang Departemen Agama. (2005): laporan akhir penelitian Pola Aktivitas Kelompok Keaagamaan di Kalangan Mahasiswa Pasca Reformasi (Studi Kasus di 6 PTUN). Jakarta, Balitbang Departemen Agama.

Majid, Nurcholish. (2002): "Demokrasi: Kerukunan dan Kebenaran", dalam A. Makmur Makka, ed. Demokrasi Tak Boleh Berhenti. Jakarta: The Habibie Center..

Mizan, Aguk I. (2011): "Melacak Akar Radikalisme dalam Gerakan Islam Modern", Analisis, Vol. XI, No. 1.

Mubarak, M. Zaki. (2008): Genealogi Islam Radikal di Indonesia: Gerakan, Pemikiran dan Prosepek Demokrasi. Jakarta, LP3ES.

Saifuddin. (2011): "Radikalisme Islam di Kalangan Mahasiswa (Sebuah Metamorfosa Baru", Analisis, Vol. XI, No.1.

Shepard, W. (1987): "Fundamentalism Christian and Islamic," Religion, Vol. 17.

Sujatmiko, Iwan G. (1996): "Stratifikasi Sosial dan Mobilitas Sosial", Jurnal Sosiologi Indonesia, No. 1.

Tim Survei, Laporan Penelitian. (2011): Ancaman bagi Ideologi Negara melalui Radikalisme Agama, Jakarta: Lembaga Penelitian UHAMKA.

Tim Survei, Laporan Penelitian. (2011): Ancaman bagi Ideologi Negara melalui Radikalisme Agama. Jakarta, Lembaga Penelitian Uhamka.

Wilson, A.N. (1992): Against Religion: Why We Should Live without It, London, Chatto and Windus.

Yunanto, S., et.al. (2003): Gerakan Militan Islam di Indonesia dan di Asia Tenggara, Jakarta, The Ridep Institute. 